\title{
THE EFFECT OF EDUCATIONAL INTERVENTION ON THE PATIENT'S WILLINGNESS TO CARRY OUT THE IMMUNOCHEMICAL FAECAL OCCULT BLOOD TEST FOR COLORECTAL CANCER VPLIV IZOBRAŽEVALNEGA UKREPA NA PACIENTOVO PRIPRAVLJENOST ZA IZVEDBO IMUNOKEMIČNEGA TESTA ZA DOLOČANJE OKULTNE KRVI V BLATU ZA RAKA DEBELEGA ČREVESA IN DANKE
}

\author{
Rositsa TSVETANOVA DIMOVA ${ }^{1 *}$, Donka DIMITROVA DIMITROVA ${ }^{1}$, Rumiana GENCHEVA STOYANOVA ${ }^{1}$, \\ Boriana ANGELOVA LEVTEROVA ${ }^{1}$, Nikolay GEORGIEV ATANASOV ${ }^{1}$, Radost SPIRIDONOVA ASSENOVA ${ }^{1}$
}

${ }^{1}$ Medical University of Plovdiv, Healthcare Management, Health Economics and Primary Care, 15a V. Aprilov Blvd., Plovdiv 4002, Bulgaria

Received/Prispelo: Oct 6, 2014

Accepted/Sprejeto: Apr 1, 2015
Original scientific article/lzvirni znanstveni članek

\section{ABSTRACT \\ Keywords: \\ screening, colorectal cancer, immunochemical faecal occult blood test, general practitioner}

\section{IZVLEČEK}

Ključne besede: presejanje, rak debelega črevesa in danke, imunokemični test za določanje okultne krvi $\checkmark$ blatu, splošni zdravnik
Background. There is now compelling evidence that screening for colorectal cancer may result in significantly reduced mortality. Screening tests for colorectal cancer are not systematically performed in Bulgaria.

Aim. This article explores the effect of an educational intervention on the willingness of patients to participate in the screening for colorectal cancer with the immunochemical faecal occult blood test in the home setting.

Materials and methods. A before-after design study of the effects of educational intervention comprising distribution of a brochure and one-to-one discussion with a GP. A self-administered, original questionnaire was administered before and after the intervention to 600 randomly selected patients in 40 general practices (15 patients per practice) in Plovdiv district.

Results. The intervention led to an increase with $>20 \%$ of the patient's knowledge of the importance of the test and on how to carry out the test. Statistical analysis indicated that there was an increase in knowledge after the educational intervention about the usefulness of the test $(24.8 \%$ in males, $18.3 \%$ in females) and its performance (22.7\% in males, $25.4 \%$ in females).

Conclusion. The educational intervention has significantly influenced the patient's awareness about the test's usefulness and its self-administration. It improved the awareness by providing an easy access to information, thus fostering the active involvement of the patients. A strength of the intervention was the patient-centered approach in providing additional information through one-to-one discussions, and it ensured a higher quality of the preventive screening in the general practice.

Uvod. Sedaj obstajajo prepričljivi dokazi, da presejanje za raka debelega črevesa in danke lahko bistveno zniža stopnjo smrtnosti. Presejalni testi za raka debelega črevesa in danke se $v$ Bolgariji ne izvajajo sistematično.

Cilj. Članek raziskuje učinek izobraževalnega ukrepa na pripravljenost pacientov za presejanje za raka debelega črevesa in danke z imunokemičnim testom na domu za določanje okultne krvi v blatu.

Metode. Študija "prej in potem" učinka izobraževalnega ukrepa, ki vključuje razdeljevanje brošure in osebni pogovor s splošnim zdravnikom. Prvotni vprašalnik je bil pred in po ukrepu razdeljen 600 naključno izbranim pacientom in 40 splošnim ambulantam (15 pacientov na ambulanto) $v$ okraju Plovdiv.

Rezultati. Ukrep je prinesel več kot 20 \% povečanje zavedanja pacientov o pomenu testa in o načinu njegove izvedbe. Statistična analiza je pokazala, da po izobraževalnem ukrepu obstaja porast znanja o uporabnosti testa (24,8 \% pri moških, 18,3 pri ženskah) in njegovem delovanju (22,7 \% pri moških, $25,4 \%$ pri ženskah).

Zaključek. Izobraževalni ukrep je bistveno vplival na pacientovo zavedanje o uporabnosti testa in njegovi izvedbi. Povečal je zavedanje z zagotavljanjem enostavnega dostopa do informacij in $s$ tem spodbudil aktivno udeležbo pacientov. Ukrep je bil uspešen zaradi pristopa, usmerjenega k pacientu, pri zagotavljanju dodatnih informacij prek osebnih pogovorov in je prinesel višjo kakovost preventivnega presejanja $v$ splošnih ambulantah.

*Corresponding author: Tel: +358 08873630 22; E-mail: ros_dimova@yahoo.com 


\section{INTRODUCTION}

Compelling evidence exists from randomised controlled trials that screening for colorectal cancer (CRC), using faecal occult blood tests (FOBT), may result in significantly reduced incidence and death rates from CRC (1). The Council's recommendation on cancer screening (2003/878/ EC) encourages EU Member States to develop appropriate actions and measures in implementing national cancer screening programs with a population-based approach. However, by the end of 2007, only few EU Member States have organized widespread mass screening with this test (2). National programs and guidelines for CRC screening in different countries have made recommendations based on the following finding from a number of randomised clinical trials: FOBT may be carried out with equal success both at home and in outpatient practice or physicians' offices (3-9). It has been shown that patients use a home-based FOBT more commonly than an office-based FOBT (2). The good practice, or 'the gold standard' adopted worldwide, requires that, in cases of positive screening test results for occult blood loss, a further diagnostic evaluation by colonoscopy and active follow-up are performed (1, 9, 10).

The involvement of a physician, especially GPs, in CRC screening can be very effective in improving compliance, according to the findings of several studies from different countries (11-14). However, organisational measures should be implemented and primary health care providers, including general practitioners (GPs), should be adequately trained in order to ensure that they are able to deliver high quality screening $(2,14$, 15). Increasing knowledge and awareness of healthy individuals were associated with higher intentions to participate in colorectal cancer screening $(12,16)$. Unlike other countries, where FOBT is a part of organized screening programs, currently no systematic populationbased screening for CRC is performed in Bulgaria (1-5, 8, 11). The Bulgarian National Centre on Health Information and Analysis provides data on the prevailing tendency of increasing morbidity and mortality rates due to CRC $(17,18)$. The Bulgarian healthcare system is designed as a three-stage model, with GPs as gate keepers. GPs are financed per capita and some additional payments for prophylactic activities not including CRC screening. However, by 2009 the screening for CRC with gFOBT was non-population-based and conducted with the assistance of GPs. This was discontinued due to poor compliance between GPs and health insured persons. The present study was inspired by the evidence from different countries across the world, that performance of the iFOBT in the home setting stimulated patient involvement and improved efficiency and effectiveness of CRC screening $(2,14,19,20)$. To date, there are no published studies of patients' views about CRC screening with iFOBT in Bulgaria.

The aim of this study was to explore the effect of an educational intervention on the willingness of patients to participate in the screening for CRC by the immunochemical faecal occult blood test in a home setting.

\section{METHODS}

\subsection{Study Design}

This before-after design study is part of a University Research Project № 06/2011, entitled: 'Patient-centred approach to increase promotional activity and screening for CRC in general practice' (http://meduniversityplovdiv.bg/bg/nauchna_dejnost/menu vup/1664-vup2).

The current study evaluated the intervention effect on patients' willingness to participate in the screening for CRC. The study took place in the period from June to September 2011 in the practices of the participating GPs. The effect of the educational intervention was studied by two anonymous and self-administered questionnaires (pre-coded for identification) completed before and after the administration at a single visit to the GP practices. After being informed and instructed, consenting patients completed the first questionnaire in a waiting room, and returned it prior to receiving a brochure and a one-to-one discussion delivered by the GP. After the patients saw their GP and had time to read the brochure, they were asked to complete the second questionnaire (identical to the first one) and return it to the GP office. If reminders were needed, the patients were asked to return the completed questionnaire to the GP office in one week.

\subsection{Ethics}

The overall design of the study, interventions, tools and informed consent forms were approved by the Ethics Committee of the Medical University of Plovdiv, Protocol №2/24.03.2011.

\subsection{Recruitment}

The estimated minimum sample size of patients was 384 , based on the results from a pilot study of proportions of studied variables - the importance of the test and sufficiency of information and an error of $5 \%$. Since the expected percentage of non-response to questionnaire surveys is very high in Bulgaria, considering the probability of missing data or participation drop-out, this number was increased to 600 .

Inclusion criteria: health-insured at an average risk for CRC (asymptomatic individuals aged over 45 years) who had had at least one consultation with a GP in the previous 12 months. 
Exclusion criteria: people with previous colorectal cancer, adenomas, inflammatory bowel disease, a recent $(\leq 2$ years) colorectal endoscopy, or two first-degree relatives with colorectal cancer were excluded.

A two-stage sampling technique was used to recruit the participants. In the first stage: Through the coordinator of the local association of GPs and personal e-mails, 100 GPs were invited ( $50 \%$ sample of all GPs from the Plovdiv municipality), of which $40 \mathrm{GPs}$ responded. In the second stage: 15 health-insured individuals were recruited from each GP practice - a total of 600 . Eligible subjects were randomly selected using a lottery method, within the roster of their general practitioner.

\subsection{Intervention}

The adopted approach aimed at supporting an active involvement of patients in the decision-making about their health, their engagement and empowerment by purposeful education and encouragement of good compliance with GPs (21).

The educational intervention was designed and implemented to influence the willingness of patients to participate in CRC screening. A specially designed information brochure was given to the patients and additional information concerning CRC screening was provided through one-to-one discussion with their GP.

The brochure contained illustrations and concise information on CRC prevalence and risk factors, screening target populations, a description of potential benefits and harm or risk of the screening, the essence of the test and instructions for its application in a home setting. The brochure is available from the corresponding author upon request.

The distribution of the brochure was intended to facilitate a direct effect with the opportunity for later reference at home. The use of one-to-one discussions in our study is consistent with the recommendations from updated systematic reviews about various interventions to increase the participation in the screening for CRCs with FOBT $(14,22)$.

\subsection{Questionnaire and Measures}

The questionnaire was developed on the basis of preliminary conceptual model for patient education. Tools used in other screening studies in Bulgaria were also explored (23). The initial version of the questionnaire was discussed with GPs, surgeons and gastroenterologists, then revised and piloted in the study of 60 patients.

The questionnaire included 10 questions and was administered twice (before and after the intervention), and it consisted of a single choice closed and semi-open ended questions in several panels: The first panel included demographics (gender, age, level of education), i.e. explanatory phenomena (EP); the second panel - observed outcomes (00): significance and usefulness of the test $\mathrm{OO}(1)$; personal interest and readiness to perform the test at home - $\mathrm{OO}(2)$; preferred sources of receiving additional health information - OO(3); preferred method to obtain health information - 00 (4). The answers of semi-open questions were to be submitted for additional analysis and classification before the final data processing. However, none of the respondents used the option for semi-open questions.

The results indicated that the original anonymous questionnaire had sufficient face and construct validity and reliability. Cronbach's Alpha (a) was from 0.81 to 0.86 for the results concerning changes in awareness and willingness of patients to perform iFOBT.

\subsection{Statistical Analysis}

The data is presented as mean and standard deviation $( \pm$ SD) or number (percentage), as appropriate. All percentages were computed on the basis of all 499 respondents, both before and after the educational intervention, unless stated otherwise. The following statistical analyses were used:

- descriptive statistics presents the frequency distribution, mean and standard deviation;

- non-parametric analyses ( $x^{2}$ test - testing of hypotheses between categorical variables; Wilcoxon signed-rank test - it tests the hypotheses of differences between two related samples; Mann-Whitney test - it tests the hypothesis of differences between two independent samples).

- logistic regression analysis ( 0 - not readiness and not willingness, 1 - readiness and willingness) is used to determine which factors exert influence on the readiness of the respondents to perform the test.

A two-sided significance level of 0.05 was applied. The data was elaborated and analysed using the software package SPSS version 17.0.

\section{RESULTS}

\subsection{Patient Characteristics}

The response rate was $83.2 \%$ (499 patients from the initially approached 600), based on the number of patients who returned and correctly completed both parts of the questionnaire (before and after the educational intervention).

The analysis of socio-demographic characteristics (gender, age and education) between the study participants and non-participating patients, according to the GPs, showed 
no significant differences $(P=0.086)$, which allowed us to accept these results as representative of the surveyed population.

The mean age of respondents was $54.9 \pm 9.8$ years. Sociodemographic characteristics of patients are presented in Table 1.

Table 1. Socio-demographic characteristics of patients.

\begin{tabular}{|c|c|}
\hline Parameters & N (\%) \\
\hline \multicolumn{2}{|l|}{ Gender } \\
\hline Male & $145(29.1 \%)$ \\
\hline Female & 354 (70.9\%) \\
\hline \multicolumn{2}{|l|}{ Age } \\
\hline$\leq 50$ & $203(40.8 \%)$ \\
\hline $51-60$ & $166(33.4 \%)$ \\
\hline $61-70$ & $89(17.8 \%)$ \\
\hline$\geq 71$ & $40(8.0 \%)$ \\
\hline \multicolumn{2}{|l|}{ Level of education } \\
\hline High & $236(47.3 \%)$ \\
\hline Medium & $228(45.7 \%)$ \\
\hline Low & $35(7.0 \%)$ \\
\hline
\end{tabular}

\subsection{Willingness to Participate in CRC Screening}

The proportion of the surveyed group who was ready and willing to carry out the CRC test before and after the education was relatively high - $85.8 \%$ and $87.3 \%$, respectively. The results showed that, after the intervention, the awareness and knowledge of the target group significantly increased (Table 2 ).

Table 2. Patients' opinions on the importance, usefulness and procedures for the performance of iFOBT.

\begin{tabular}{|c|c|c|c|c|}
\hline Questions & Answers & $\begin{array}{c}\text { Before education* } \\
\text { N (\%) }\end{array}$ & $\begin{array}{c}\text { After education* } \\
\mathrm{N}(\%)\end{array}$ & P-value \\
\hline \multirow{3}{*}{$\begin{array}{l}\text { Is it important for you to take } \\
\text { this test? }\end{array}$} & Yes / Yes, I do & 369 (78.5) & $403(80.9)$ & \multirow{3}{*}{$P=0.502$} \\
\hline & $\begin{array}{l}\text { No (not entirely } \\
\text { or not at all) }\end{array}$ & $56(11.9)$ & $50(10.1)$ & \\
\hline & I cannot answer & $45(9.6)$ & $45(9.0)$ & \\
\hline \multirow{3}{*}{$\begin{array}{l}\text { Do you have enough information } \\
\text { about the usefulness of the test? }\end{array}$} & Yes / Yes, I do & $248(50.3)$ & 347 (70.4) & \multirow{3}{*}{$P=0.001$} \\
\hline & $\begin{array}{l}\text { No (not entirely } \\
\text { or not at all) }\end{array}$ & $245(49.7)$ & $146(29.6)$ & \\
\hline & I cannot answer & - & - & \\
\hline \multirow{3}{*}{$\begin{array}{l}\text { Do you have enough information } \\
\text { on how to carry out the test? }\end{array}$} & Yes / Yes, I do & $229(46.4)$ & 353 (71.7) & \multirow{3}{*}{$P=0.001$} \\
\hline & $\begin{array}{l}\text { No (not entirely } \\
\text { or not at all) }\end{array}$ & $265(53.6)$ & $139(28.3)$ & \\
\hline & I cannot answer & - & - & \\
\hline
\end{tabular}

*Note: All numbers (percentages) are computed out of all respondents with valid answers (out of all 499 respondents). 
The analysis confirmed the usefulness of educational materials. After having read the brochure and the discussion with a GP, the proportion of those who needed more information about iFOBT significantly decreased by $26.0 \%$ (124) $(P=0.005)$.

When asked 'In your opinion, who may inform you best on the test?' the respondents rated as first their general practitioner, followed by other physicians. Having a discussion with a physician, regardless of his/her specialty, was considered the best way to get informed on the screening and on early diagnosis of malignancies of the digestive system, which confirmed the general confidence patients had in physicians (Table 3).

Table 3. The influence of gender on the measured indicators before and after education.

\begin{tabular}{|c|c|c|c|c|c|c|}
\hline \multirow[t]{2}{*}{ Questions } & \multicolumn{3}{|c|}{ Before educationt } & \multicolumn{3}{|c|}{ After education $\dagger$} \\
\hline & $\begin{array}{l}\text { Male, } \\
\mathrm{N}(\%)\end{array}$ & $\begin{array}{l}\text { Female*, }^{*} \\
\text { N (\%) }\end{array}$ & $P$ value & $\begin{array}{l}\text { Male, } \\
\mathrm{N}(\%)\end{array}$ & $\begin{array}{l}\text { Female*, } \\
\text { N (\%) }\end{array}$ & $P$ value \\
\hline \multicolumn{7}{|c|}{ Readiness to perform the test } \\
\hline Yes, I am willing & $111(80.3)$ & $307(88.2)$ & & $115(81.6)$ & $317(89.8)$ & \\
\hline No & $17(12.0)$ & $21(6.0)$ & $P=0.049$ & $22(15.6)$ & $25(7.1)$ & $P=0.014$ \\
\hline I cannot answer & $11(7.7)$ & $20(5.8)$ & & $4(2.8)$ & $11(3.1)$ & \\
\hline \multicolumn{7}{|c|}{ Preferred sources for obtaining health information } \\
\hline General Practitioner & $85(59.4)$ & $307(88.2)$ & & $85(59.4)$ & $174(49.3)$ & \\
\hline Other specialty physician & $56(39.2)$ & $21(6.0)$ & $P=0.427$ & $56(39.2)$ & $178(50.4)$ & $P=0.040$ \\
\hline Other (relative/friend) & $2(1.4)$ & $20(5.8)$ & & $2(1.4)$ & $1(0.3)$ & \\
\hline \multicolumn{7}{|c|}{ Preferred method to obtain health information on early diagnosis of digestive system diseasestt } \\
\hline Discussion with the GP & $98(68.5)$ & $198(56.3)$ & $P=0.015$ & $93(65.0)$ & $196(55.5)$ & $P=0.050$ \\
\hline $\begin{array}{l}\text { Discussion with other specialty } \\
\text { physician }\end{array}$ & $77(55.8)$ & $201(56.9)$ & $P=0.529$ & $80(55.9)$ & $207(58.6)$ & $P=0.582$ \\
\hline Reading printed materials & $39(27.3)$ & $112(31.8)$ & $P=0.319$ & $35(24.5)$ & $110(31.3)$ & $P=0.133$ \\
\hline Searching Internet & $26(18.3)$ & $80(22.7)$ & $P=0.279$ & $24(16.8)$ & $80(22.7)$ & $P=0.145$ \\
\hline Via the media (radio or TV) & $23(16.1)$ & $43(12.3)$ & $P=0.256$ & $20(14.0)$ & $39(11.0)$ & $P=0.360$ \\
\hline
\end{tabular}

† All numbers (percentages) are computed out of all respondents with valid answers (out of all 499 respondents)

* Male vs female

†† The total percentage exceeds $100 \%$, due to the possibility for indicated of more than one answer.

\subsection{Comparative Analyses of Significant Differences by Demographic Characteristics}

The results revealed that the demographic characteristics of respondents - gender, age and level of education - affect their motivation and understanding of the usefulness and procedures of iFOBT.

The female respondents in $88.2 \%$ (312) showed greater motivation to perform iFOBT before $(P=0.049)$ and after the educational intervention $(P=0.014)$. The level of education influenced attitudes and motivation of respondents to perform iFOBT. University and college graduates expressed higher motivation to perform the test than those with less than a college educational degree $(P=0.001)$. With the help of binary multiple logistic regression an assessment of the influence of sociodemographic factors on the readiness of the respondents to perform the test before and after the training was made. Before training women (OR: 1,752; 95\% Cl: 1,0193,010 ) and respondents with higher education (OR: 1,676; $95 \% \mathrm{Cl}: 1,286-2,183)$ display higher willingness to perform the test. The model with 2 variables (gender and attained degree of education) accounts for only $7 \%$ of readiness. Following education, the only determinant is gender, and 
again women are more willing to perform the test (OR: 1,907; 95\% Cl: 1,096-3,316).

Statistical analysis indicated that there was an increase in knowledge after education about the usefulness of the test (24.8\% in males, $18.3 \%$ in females) and its performance (22.7\% in males, $25.4 \%$ in females). Respondents with advanced level of education (College and University) were better informed about the usefulness of the test $(P=0.011)$ and how to perform the test $(P=0.004)$ after the health education in comparison to those with lower educational level. People up to 60 years of age (356 (71\%)), assessed the materials provided as 'definitely sufficient', they were more aware of the usefulness of the test $(P=0.003)$ and how to perform it at home $(\mathrm{P}=0.004)$, compared to the older participants.

There was, however, a significant difference in preferences of female and male respondents on sources and ways of obtaining information related to prevention and early diagnosis. About $60 \%$ (85) of male and $49.3 \%$ (174) of female participants preferred GPs as a source of information ( $P=0.040)$ and a discussion with him/her about the early diagnosis of different intestinal tract diseases $(P=0.015)$ (Table 3). Persons with less than college level education tended to and preferred discussing the early diagnosis of digestive system diseases with a narrow specialty physician $(P=0.037)$, than discussing it with their $\mathrm{GP}$, which may suggest less confidence in their GPs.

Respondents over 71 years of age preferred to be informed on the early diagnosis of various intestinal tract diseases by different broadcast media (radio, TV programs) $(P=0.009)$. Participants with advanced level of education showed a tendency to use more often the Internet as a source of information on the early diagnosis of different diseases of the gastrointestinal tract than other respondents $(P=0.005)$. No significant gender differences were established in the preferences of other information methods and sources - printed materials, followed by the Internet, media etc.

\section{DISCUSSION}

\subsection{Main Findings}

The majority of the respondents believed that iFOBT was very important for them and they were willing to perform it at home. A significant increase of patients' knowledge about the utility of the test and the way of performing it showed effectiveness of the educational intervention. Referring to sources of information, the respondents showed no significant preference (before and after education) of GPs to other specialists, which confirmed general confidence patients had in physicians. The study revealed that patients' preferred way of receiving information on early diagnosis was primarily one-to-one discussion with physicians, regardless of their specialty; this was followed by printed media, the Internet and other media. The reduction in patient's confidence in GPs following intervention on account of another medical specialist might be explained with the fact that, in Bulgaria, GPs are still not sufficiently trained to carry out activities related to health promotion - health education and oncological disease screening $(25,26)$.

We speculate that GPs should be effective mediators and coordinators of health promotion activities, and that they can play an important role in the implementation of a patient-centred approach.

The respondents with an advanced level of education expressed a greater willingness to perform iFOBT, higher trust in GPs and more frequent use of the Internet than those with a lower educational level. The younger respondents found the educational brochures more useful, while elderly people indicated broadcasting media, such as radio and TV, as their preferred source of healthrelated information.

\subsection{Other Findings}

The data consistently indicates that the lack of awareness of CRC represents one of the main determinants of the low rate of participation in screening. Provision of information is necessary to enable subjects to make an informed choice, but it is not sufficient to enhance participation (2).

Previous studies have found improved compliance of the surveyed target group in the performance of gFOBT after participation in educational programs. Face-to-face education (with nurse and/or GP) was clearly useful in improving knowledge, helping patients to make informed decisions and increasing CRC screening participation rates $(14,22,24)$. Other authors reported increased use of iFOBT, which was consistently higher among women than men (5). Brawarsky and Brooks found that the level of education was not associated with adherence to testing. Furthermore, while men and women were equally likely to have a test recommendation, men were more likely to adhere and more likely to be currently tested (13).

Remuneration is one of GP's reasons for promoting CRC screening in both our studies and in the study of Berchi et al. (12). Other factors influencing GPs' screening practice were the effectiveness of the screening programme and, particularly, the sensitivity of FOBT.

Most GPs approve of their participation in such programs and think that this is particularly important in the prevention of cancer (11).

The study of Brawarsky and Brooks confirmed the role of physicians and reported a strong positive association between having a primary doctor, receiving a CRC recommendation and having a test (13). Previously, 
our research implied that GPs were more likely to have negative attitudes towards gFOBT (25). General practitioners in Bulgaria do not perform group education and other interventions, described in similar studies, due to various factors (individual practices, the shortage of staff, administrative tasks overload) $(21,23,25,26)$. We could assume that, if provided with adequate incentives, GPs would increase their motivation and performance in future population-based CRC screening programmes, as in other countries (12).

\subsection{Strengths and Limitations of the Study}

This is the first survey of its kind in Bulgaria, with a high response rate. To avoid the influence of confounding factors, we conducted both surveys within a single visit to a GP immediately before and after the educational intervention.

The higher proportion of respondents with higher education in this study compared with the general population may be associated with the fact that the persons recruited were health-insured and over 45 years of age, suggesting that they may have had a better socio-economic status (27). Another limitation is a higher proportion of females in the sample. We also acknowledge that the study is limited by subjective assessments of the target group that may have potentially produced biased results, since the authors could not refer to the respondents' actual experience in carrying out iFOBT and further research is needed, in this regard.

\subsection{Implications of the Study Results for Public Health}

Implications of the population-based screening for primary care should be considered and further studied.

\subsection{Possibilities for Future Research in the Field}

Research is necessary, to understand the actual accomplishment of iFOBT from the target population after proper educational interventions. However, we believe that the results might be of relevance to countries facing similar challenges as Bulgaria, such as the former socialist countries and countries in the Balkan region.

\section{CONCLUSION}

Significant effect of educational intervention was established. The education led to increased patients' knowledge of the importance of the test and the mode if its application. Patients' gender and education level were identified as potential factors of the willingness to carry out the test. GPs were seen as a valuable and preferred source of information concerning health promotion. These results could serve as a basis for further research to examine iFOBT acceptability by studying actual performance in the home setting. The educational brochure proved to be effective and may be used in future educational programmes and in the development of online tools.

\section{ACKNOWLEDEMENTS}

This study was performed with financial support of Medical University of Plovdiv by grant within the University Research Project №06/2011 in the collection of the data. The authors would like to thank for kind support and collaboration of the colleagues from the University. We are grateful to all GPs and participants who took part in this survey.

\section{CONFLICTS OF INTEREST}

The authors declare no conflicts of interest.

\section{FUNDING}

The study is a part of a Medical University of Plovdiv Research Project № 06/2011, entitled: 'Patient-centred approach to increase promotional activity and screening for CRC in general practice'.

\section{ETHICAL APPROVAL}

The overall design of the study, interventions, tools and informed consent forms were approved by the Ethics Committee of the Medical University of Plovdiv.

\section{REFERENCES}

1. Mandel JS, Church TR, Bond JH, Ederer F, Geisser MS, Mongin SJ, et al. The effect of fecal occult-blood screening on the incidence of CRC. N Engl J Med 2000; 343: 1603-7.

2. Cancer screening in the European Union: report on the implementation of the Council. Available Jan 14, 2014 from: http:// ec.europa.eu/health/ph_determinants/genetics/documents / cancer_screening.pdf

3. Haug $U$, Hundt S, Brenner $H$. Quantitative immunochemical fecal occult blood testing for colorectal adenoma detection: evaluation in the target population of screening and comparison with qualitative tests. Am J Gastroenterol 2010; 105: 682-90.

4. Nadel MR, Shapiro JA, Klabunde CN, Seeff LC, Uhler R, Smith RA, et al. A national survey of primary care physicians' methods for screening for fecal occult blood. Ann Intern Med 2005; 142: 86-94.

5. Steele RJC, Kostourou I, Clements PM, Watling C, Libby G, Weller $D$, et al. Effect of gender, age and deprivation on key performance indicators in a FOBT-based colorectal screening programme. J Med Screen 2010; 17: 68-74. 
6. Segnan N, Senore C, Andreoni B, Arrigoni A, Bisanti L, Cardelli A, et al. Randomized trial of different screening strategies for CRC: patient response and detection rates. J Natl Cancer Inst 2005; 97: 347-57.

7. Shastri YM, Loitsch S, Hoepffner N, Povse N, Hanisch E, Rösch W, et al. Comparison of an established simple office-based immunological FOBT with fecal tumor pyruvate kinase type M2 (M2-PK) for colorectal cancer screening: prospective multicenter study. Am J Gastroenterol 2008; 103: 1496-1504.

8. The American Cancer Society. Global cancer facts \& figures. 2nd ed. Atlanta: American Cancer Society, 2011.

9. The guide to medicare preventive services for physicians, suppliers and other health care professionals, CMS, Dept. of Health and Human Services- USA, 2005. Available Jan 13, 2014 from: http://www.cms. gov/Outreach-and-Education/Medicare-Learning-Network-MLN/ MLNProducts/downloads/psguid.pdf.

10. Church TR, Yeazel MW, Jones RM, Kochevar LK, Watt GD, Mongin SJ, et al. A randomized trial of direct mailing of fecal occult blood test to increased CRC screening. J Natl Cancer Inst 2004; 96: 770-80.

11. Seifert B, Zavoral M, Fric P, Bencko V. The role of primary care in colorectal cancer screening: experience from Czech Republic. Neoplasma 2008; 55: 74-80.

12. Berchi C, Dupuis JM, Launoy G. The reasons of general practitioners for promoting CRC mass screening in France. Eur J Health Econ 2006; 7: $91-8$.

13. Brawarsky P, Brooks DR. Effect of physician recommendation and patient adherence on rates of CRC testing. Cancer Detect Prev 2004; 28: 260-8.

14. European guidelines for quality assurance in colorectal cancer screening and diagnosis. Available Jan 10, 2014 from: http:// www.kolorektum.cz/res/file/guidelines/CRC-screening-guidelinesEC-2011-02-03.pdf

15. Faivre J, Dancourt V, Lejeune C. Screening for colorectal cancer with immunochemical faecal occult blood tests. Dig Liver Dis 2012; 44: 967-73.

16. McCaffery K, Wardle J, Waller J. Knowledge, attitudes, and behavioral intentions in relation to the early detection of colorectal cancer in the United Kingdom. Prev Med 2003; 36: 525-35.
17. National Centre on Health Information and Analysis. Mortality by main causes in the Republic of Bulgaria, 2011. Available Jan 10, 2014 from: http://ncphp.government.bg/files/nczi/izdania_2010/ buletin_Death_11.pdf , last access

18. Damyanov D, Kurtev P. Present state and perspectives in CRC treatment. Scr Sci Med 2007; 39(Suppl): 217-21.

19. Jatoi I, Anderson WF. Cancer screening. Curr Probl Surg 2005; 42: 620-82.

20. van Dam L, Hol L, de Bekker-Grob EW, Steyerberg EW, Kuipers EJ, Habbema JD, et al. What determines individuals' preferences for colorectal cancer screening programmes? A discrete choice experiment. Eur J Cancer 2010; 46: 150-9.

21. Dimova R, R. Stoyanova, B. Levterova, R. Dimov. 'Doctor-patient compliance' in introducing of fecal immunochemical occult blood test - cross - sectional survey in Bulgaria. Euras J Fam Med 2012; 2: 55-62.

22. Sabatino SA, Lawrence B, Elder R, Mercer SL, Wilson KM, DeVinney B, et al. Effectiveness of interventions to increase screening for breast, cervical, and CRCs: nine updated systematic reviews for the guide to community preventive services. Am J Prev Med 2012; 43: 97-118.

23. Chachevski N. Screening in the general medical practice: $\mathrm{PhD}$ thesis. Plovdiv: Faculty of Public Health, Medical University, 2009.

24. Wee CC, MCCarthy EP, Phillips RS. Factors associated with colon cancer screening: the role of patient factors and physician counseling. Prev Med 2005; 41: 23-9.

25. Dimova R, Dimov R. Attitudes, motivation and behavior of general practitioners toward performance of colorectal carcinoma screening programme. General Medicine 2007; 9: 6-11

26. Dimitrova D. Factors limiting the participation of patients in screening programs. In: Scientific conference 4-5. 11. 2009: proceedings. Plovdiv: Union of Scientists in Bulgaria, Scientific Researchers of the Union of Scientists in Bulgaria, 2010: 108-12.

27. Census 2011 in Bulgaria. Available Jan 6, 2014 from:

28. http://www.nsi.bg/census2011/PDOCS2/Census2011final_en.pdf 